\title{
Reflections: Graduate Education in Comparative Politics in the Mid-Twentieth Century
}

\author{
Gerhard Loewenberg, University of Iowa
}

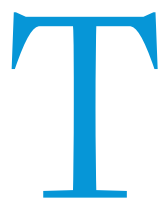

he organization of graduate education in political science has changed substantially in the years since I entered the profession. Graduate programs are more numerous, graduate enrollments are much higher, and the literature in the field has expanded greatly. There is today more hands-on supervision of graduate work and a much clearer definition of the increasingly specialized subfields of the discipline. It is interesting to compare my own education in comparative government in the middle of the twentieth century to graduate education today because the contrast illustrates how the expectations of students have changed as well as how the subfield of comparative politics has been redefined. In my time, graduate students received little guidance for their dissertation research once a faculty director had approved the topic. Certainly, a student could not expect the director to read numerous drafts. This made the submission of a completed, penultimate draft a moment of real apprehension. Furthermore, a student could not have done all of the research for a comparative politics dissertation in a data lab without at least participating in data gathering and gaining experience in "the field."

The discipline of political science in the United States developed under the influence of heavy enrollments in American government courses-the "bread and butter" of the discipline-and that emphasis on a single political system shaped the organization of undergraduate courses in comparative government. They were organized by country and designed to introduce students to systems of government outside of the United States. Graduate work and faculty research in the comparative field was similarly country-specific. It required an acquaintance with the history and political culture of the relevant "foreign" country and generally substantial time spent there. Most research questions focused on a particular geographic setting, but they might be formulated to have cross-national or cross-temporal implications. This country-specific approach began to change in the years after the Second World War, in part under the influence of a cohort of European émigré scholars who came to the United States in the first half of the twentieth century and in part as a result of America's growing involvement in the wider world.

My own introduction to comparative government in the late 1940 s at Cornell University was in courses taught by Mario Einaudi, a member of the group of European scholars whose influence on comparative politics in the United States I have described elsewhere (Loewenberg 2006). In Europe, the study of government had taken place in the faculties of law and political theory, emphasizing institutions and theory. It did not focus on the government of a student's own country. Einaudi, who had been educated in Italy at the University of Turin, regarded

Gerhard Loewenberg is Foundation Distinguished Professor and Professor Emeritus at the University of Iowa. He can be reached at g-loewenberg@uiowa.edu. the introduction to a set of governments as an opportunity to introduce broad concepts of governance, using different political systems to illustrate. He had written a dissertation on Edmund Burke and a book on the eighteenth-century French physiocrats, in whose writings he identified sources of the American concept of judicial review. During the course of my own graduate work, he published books on communism in Western Europe and on Christian democracy in Italy and France (Katzenstein, Lowi, and Tarrow 1990). When he

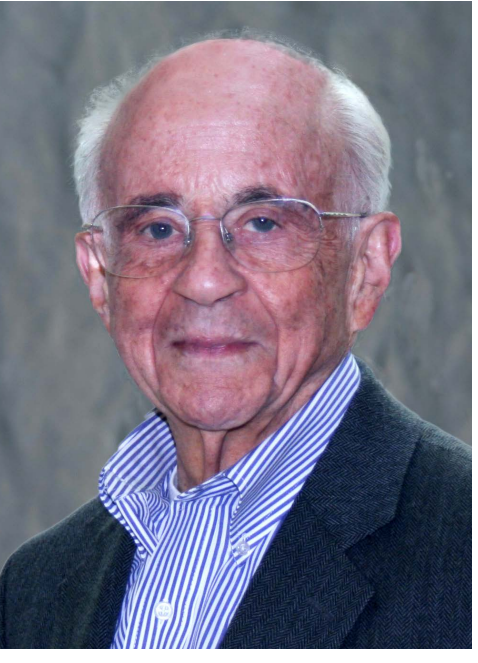

Gerhard Loewenberg, Foundation Distinguished Professor and Professor Emeritus, University of lowa was invited to contribute the chapters on French and Italian governments to a comparative government textbook in this country in 1949, he insisted on treating France and Italy together. He wrote to the publisher that he was "convinced that the curse of comparative government textbooks is the special country by country treatment." (Einaudi, 1950). In this, he was ahead of his time and the editor rejected his approach. He also was ahead of his time by including examples from American government in several of his comparative government courses. Having a special interest in economic planning, he regarded the Tennessee Valley Authority (TVA) as a model for planning elsewhere in the world, and he included David Lilienthal's book, TVA: Democracy on the March, in many of his comparative government courses (Lilienthal 1944).

European politics was in flux immediately after the Second World War. Germany was divided into four zones of occupation; France and Italy were writing new constitutions; and the British Labour Party had unexpectedly defeated Winston Churchill and, for the first time, had formed a majority government. For students like me, whose interest in politics was inspired by current events, this was a heady time. It made the subject very attractive. For his introductory undergraduate course, Einaudi used a textbook hastily revised in the fall of 1945 by a group of West Point military instructors that was designed to prepare graduates to enter the Foreign Service (Beukema, Geer, and Associates 1946). It was the only book available that provided descriptions of the politics of European countries as they existed at the end of the war. Another book that Einaudi required developed a theory of democracy by a British political theorist, Ernest Barker (Barker 1942), which reflected Einaudi's conviction that the 
description of political institutions necessitated an understanding of their theoretical foundations. Barker's theory of the parliamentary system was that it was organized to make possible "government by discussion" through four stages: from electorates to political parties to legislatures to executives. For Barker, it was necessary to understand that parliamentary democracy was not simply government by an unstructured majority.

Whereas the West Point textbook was organized into separate country chapters, as was customary, Einaudi's undergraduate lectures were organized around broad concepts. Einaudi's syllabi included topics such as ideological currents; types of parties, party systems, and political movements; social divisions and political instability; the crisis of constitutional government the role of the state in the economy; economic planning; and the totalitarian state. This meant that each week's reading assignments were scattered throughout the specific country chapters in the book. In this way, the syllabi provided a clue to understanding that "comparative government" entailed comparisons-that it was not merely a description of a set of foreign governments.

Einaudi taught all of the departmental courses that were offered in comparative government and political theory at Cornell. Departments have a period of residence in the country of their research. Einaudi continued the humanistic tradition in the study of government by his unwillingness to regard the isolated political individual rather than the political institution and the socio-cultural context of politics as the unit of analysis. The disconnect between undergraduate work in political science-still close to the humanities-and the methodsoriented requirements of graduate work was not as severe then as it has become. When, 30 years after the "behavioral revolution," a new institutionalism took hold in political science, it was partly a return to an earlier focus on institutions in the study of politics. However, the new institutionalism required the technically challenging use of formal modeling whose abstractness did not prompt a return to history and culture.

The Cornell graduate curriculum was not organized to broadly educate students in the discipline. There was neither a graduate course on the scope and methods of the discipline nor a methods requirement, although they were appearing in less traditional departments. The principal requirements at Cornell were reading competence in two languages and competence in three fields, which were demonstrated in an oral examination before beginning work on a dissertation. The fields from which students could choose were defined as American

\section{When, zo years after the "behavioral revolution," a new institutionalism took hold in political science, it was partly a return to an earlier focus on institutions in the study of politics. However, the new institutionalism required the technically challenging use of formal modeling whose abstractness did not prompt a return to history and culture.}

were much smaller than they are today and faculty members were less specialized. In addition to Einaudi, the department included Robert E. Cushman, a notable constitutional-law scholar who taught the large introductory American government course; Herbert Briggs, a specialist on international law and organization who taught all of the courses on international relations; and Elias Huzar, a mid-career specialist on Congress. A year after I began my graduate studies, the department added Clinton L. Rossiter as an instructor, who went on to become a productive scholar in the field of American political thought and institutions. The department's graduate assistants shared Rossiter's office; they had no separate office or even a desk of their own. This setting provided them with a valuable source of departmental gossip if not a place to get work done.

The principal challenge that Einaudi posed to students was his often-mistaken assumption that they would know the references to authors and events with which he peppered his lectures. In graduate seminars, he would fix his gaze on the student who was presenting a paper and say, only half questioningly, "Of course, you are familiar with ..." and name an author that none of us had ever heard of but were too intimidated to ask about. Good students took the hint and immediately looked up the reference after class.

Einaudi did not share the emerging fascination with quantifiable data. He was skeptical of explaining politics from the micropolitical perspective and regarding the study of politics as a science. It suited him that "Government" was the name of the department at Cornell, as it was at Harvard and in other traditional departments. To him, the study of politics was the study of law and institutions embedded in normative theory. He emphasized the need to understand the historical and cultural contexts of government by firsthand acquaintance with countries and cultures. He assumed that his $\mathrm{PhD}$ students would government, American constitutional law, American state and local government, comparative government, international relations and organization, and political theory.

Each of the department's faculty members offered specialized seminars in their own field. Graduate education at Cornell provided little overall awareness of the political science profession. Students were not pushed to attend political science conferences; neither did the conferences welcome graduate-student papers. Einaudi published some articles in the leading political science journals, but his work primarily appeared as books and book chapters, which were the principal forms for presenting substantial work. Einaudi largely ignored the new development of comparative politics in the 1950 S and 1960s, which expanded the purview of the field from Europe to the developing countries and increasingly relied on survey research methods and the quantitative data they produced.

Einaudi's seminars in comparative government addressed in successive semesters the new European constitutions, the political theory of a particular period and the problems of economic planning and the nationalization of industries-subjects in which he had a special interest. Required reading was extensive, in both the eighteenth- and nineteenth-century classics and recent important books. The seminar consisted of Einaudi asking questions of each student in turn, based on the assigned reading, trying to discern whether it had been understood. If a response was off the mark-as it often was-he would restate what the student had said, implying that, surely, that was what he or she had meant to say. In a seminar of a dozen students, usually only one or two were women. The seminar consisted of a kind of Socratic dialogue, which helped us to understand what careful reading required-but at some cost, at least temporarily, to our self-confidence. 
The most specific requirement of each seminar was a research paper, distributed in advance to every seminar participant. The student whose paper was the subject of a seminar meeting waited apprehensively as Einaudi leafed through it, page by page, asking about the meaning of a particular sentence, the choice of a particular word, or the neglect of a particular aspect of the topic. He offered no overall assessment of the paper; students had to guess what he thought of it by the questions he raised. Eventually, other students would chime in, but careful not to engage with Einaudi's points or to embarrass the presenter. The net effect was to develop an acquaintance with the literature relevant to the seminar topic and to provide practice in writing a seminar paper the length and scholarly apparatus of which equaled what we would currently regard as a conference paper. However, neither Einaudi nor any other faculty member suggested to a student that a paper could be presented at a professional conference, much less published.

Einaudi administered the French-language reading exam. In my case, I was asked to translate in his presence several articles from the most important French newspaper, Le Monde, without using a dictionary. Einaudi failed me the first time I took the fairly demanding test, commenting that he thought too well of me in general to pass me on my halting performance. Before the days of standardized language examinations, that method of testing informally but effectively communicated standards.

Einaudi's special interest was in the politics of Italy and France: Italy because of his concern for the reestablishment of democracy in his native country, France because he was eager to draw the parallels between French and Italian cultures. The fact that he was born in Dogliani, his family's homestead located only 80 miles from the French border, and that he spoke fluent French made him feel at home in both Italy and France. He stayed in close contact with political developments in both countries. Alarmed by the spread of communism in Western Europe, he developed a research project entitled "A French-Italian Inquiry" for which he obtained a Rockefeller Foundation grant. This work resulted in three books with European collaborators on postwar European political movements (Einaudi, Byé, and Rossi 1955; Einaudi, Domenach, and Garosci 1951; Einaudi and Goguel 1952). The project dominated his research for a decade and made his students aware of the value of a scholar's deep roots in the history and culture of political systems. The reading for Einaudi's courses and his own publications implicitly imparted an awareness of the scholarly apparatus required for research as well as the importance of work on politics outside of the United States.

Graduate seminars often raised research questions. Discussion in Einaudi's graduate-level comparative government seminar was the source of my dissertation topic, saving me from floundering on my own, which often delays a student's doctoral research. Einaudi had written about the phenomenon of the mass party-the memberoriented party typical of socialism in Europe-and the challenge it posed to parliamentary government. When Maurice Duverger's influential book, Political Parties, first appeared, Einaudi immediately required students in his comparative government seminar to read it-in the original French version (Duverger 1951). He discussed the conflict that Duverger identified between the demand of massparty members outside of parliament to decide government policy rather than permitting the party's elected legislators to make those decisions. Einaudi mentioned that this was an issue in Great Britain when the Labour Party became the governing party in 1945 , and I decided to investigate it for my doctoral research. The resulting dissertation entitled "The Effects of Governing on the British
Labour Party" led me to a lifelong interest in comparing legislatures and parliaments across countries.

To prepare for my summer of research in London, Einaudi had written letters of introduction to important British scholars. During my first week in London, on Einaudi's recommendation, I made an appointment with William Robson, the leading British scholar on the nationalization of industries. I was devastated when Robson told me that my dissertation topic was impossibly broad and asked me how an American graduate student could possibly understand British politics. In despair, I wrote to Einaudi, sending my dissertation outline and asking him whether I should scrap it. He responded quickly with a handwritten letter, which began, "Robson is a pessimist." He told me that it was always best to start a new research project with a broad definition of the topic and to narrow it down in the process of research. He told me to gather as much material on the subject as I could while in London and to refine it further when I returned home. He indicated which sections in my outline were, in his view, important and which could be relegated to a peripheral position. His mentoring was encouraging at a critical moment in my graduate research.

In a poor job market without open searches, I eagerly accepted a one-year appointment to teach at Mount Holyoke College before finishing my dissertation. It was a position that Einaudi had heard about on a lecture tour. The first year of teaching and the birth of our first baby filled my time until the following summer. Then I completed my dissertation, anxious to qualify for a tenure-track position. Einaudi never read any part of the dissertation until I submitted a complete draft. I waited three months, impatient to hear from him but not daring to contact him first. I finally received a special-delivery letter from him-three days before Christmas-that was very positive but contained no detailed criticism. He wrote as follows:

I am sorry it has taken me such a long time to let you have my conclusions about your dissertation, which I have now read in its entirety. I am very happy to tell you that I have not only read it with interest but with pleasure, and that I find it entirely acceptable as it stands. It is a fine piece of research, into which you have put a great deal of painstaking documentation and serious thought....

How are we going to proceed from this point on; is there a chance that you might spend a day with me in Ithaca going over some questions of detail? When do you intend to take the final examination?

I quickly took a train to Cornell to see him and he reviewed the dissertation with me for about an hour, making minor suggestions on details and agreeing to schedule a dissertation-defense date only two weeks later. The dissertation that resulted from his hands-off approach undoubtedly reflected the standards that he had communicated in seminars throughout my graduate career. Even though his role in my writing the dissertation was remote, it was influential because it implicitly conveyed his expectations. He exemplified the scholarly standards by which his students knew they would be judged. I later thought that the German term for a dissertation director, Doktor Vater, was quite apt.

My preparation to teach political science was influenced substantially by serving as Einaudi's teaching assistant for three semesters. I learned by watching him teach, not by any overt instruction or supervision. Student evaluations did not exist. His course syllabi were carefully developed. They contained a list of "required reading," usually in three or four different books, typically a textbook, 
a book of documents, one or two recent monographs, and the New York Times-all of which students were expected to buy. Furthermore, the syllabi listed "supplementary reading" in books on reserve at the library-lists that approached the length of bibliographies for graduate students. Each week's lectures had a topic, sometimes with subheadings, and specific reading assignments. Einaudi used notes on half sheets of paper for his lectures and his timing was close to

\section{ACKNOWLEDGMENTS}

I thank Luigi R. Einaudi, Mario Einaudi's eldest son, for making archival material at the Mario Einaudi Archive at the Fondazione Luigi Einaudi in Turin available to me, and for sending me a copy of the text of his tribute to his father delivered on the occasion of the 3oth anniversary of the Luigi Einaudi Foundation. I appreciate the assistance of Andrea Mariuzzo, a member of the Scuola Normale

\section{Graduate education in political science was-and fundamentally still is-a system of apprenticeship without a clinical component.}

perfect. He rarely exceeded the allotted 50 minutes or continued an unfinished topic in the following class.

Three characteristics of his undergraduate teaching style remained with me. Long before PowerPoint, Einaudi's lectures were models of clear organization with an appropriate amount of detail to illustrate a limited number of important points. His lectures gave careful attention to each syllabus topic and reference to the assigned reading. In class, he was sensitive to students' responses, expressed in their face and by their questions. He was always ready to stop the lecture to clarify or reiterate a point. His classes conveyed his enthusiastic interest in current political developments and the importance of government in human affairs. That spoke to the current-events origin of many students' interest in political science at that time, and to mine.

Although the original impression of Einaudi was that he was a somewhat formidable personality, students who came to know him well as teacher and mentor witnessed his commitment to their success. He was self-confident but also self-effacing; he could be intimidating but also caring. He was a voracious reader of everything even remotely related to the politics of the world that interested him, making him always a stimulating teacher. He was an example of faculty of that era who had high expectations of their students but who were often remote rather than directive, who expected initiative in their students, and who challenged them to use the broad range of their own intellectual interests. Graduate education in political science was-, and fundamentally still is-a system of apprenticeship without a clinical component. It is more formally organized today and more subdivided by subject matter than it was when I entered the profession. That has the undoubted advantage of specialization. But perhaps it also has costs, in flexibility for students to range broadly in graduate study of comparative politics, and in preserving coherence in the discipline.
Superiore di Pisa, who sent me the text of his essay, "Explaining Europe to Americans and America to Europeans: Mario Einaudi between Cultural Diplomacy and Scientific Development." My article also benefited from several conversations with Sidney Tarrow, the Maxwell M. Upson Professor of Government, Emeritus, at Cornell University, and from Professor Tarrow's introduction to the volume he coedited with Peter J. Katzenstein and Theodore Lowi, Comparative Theory and Political Experience: Mario Einaudi and the Liberal Tradition (Ithaca, NY: Cornell University Press, 1990).

\section{REF E R E N C E S}

Barker, Ernest. 1942. Reflections on Government. Oxford: Oxford University Press.

Beukema, Herman, William M. Geer, and Associates. 1946. Contemporary Foreign Governments. New York: Rinehart.

Duverger, Maurice. 1951. Les Partis Politiques. Paris: Colin. English translation: Political Parties, Their Organization and Activity in the Modern State. 1954. London: Methuen.

Einaudi, Mario. 1950. Letter to Fritz Morstein Marx, May 13, 1950. Mario Einaudi Archive at the Fondazione Luigi Einaudi, University of Turin, Italy.

Einaudi, Mario, Maurice Byé, and Ernesto Rossi. 1955. Nationalization in France and Italy. Ithaca, NY: Cornell University Press.

Einaudi, Mario, Jean-Marie Domenach, and Aldo Garosci. 1951. Communism in Western Europe. Ithaca, NY: Cornell University Press.

Einaudi, Mario, and François Goguel. 1952. Christian Democracy in Italy and France. Notre Dame, IN: University of Notre Dame Press.

Katzenstein, Peter J., Theodore J. Lowi, and Sidney Tarrow. 1990. "Bibliography of Mario Einaudi's Work." In Comparative Theory and Political Experience: Mario Einaudi and the Liberal Tradition, 213-15. Ithaca, NY: Cornell University Press.

Lilienthal, David E. 1944. TVA: Democracy on the March. New York: Harper and Brothers.

Loewenberg, Gerhard. 2006. "The Influence of European Émigré Scholars on Comparative Politics, 1925-1965." American Political Science Review $100(4): 597-604$. 